\title{
Law, Knowledge and Action in Suárez
}

\section{DAVID GONZÁLEZ GINOCCHIO}

University of South Bohemia / International University of La Rioja dgginocchio@gmail.com

\begin{abstract}
This paper explores some presuppositions in Francisco Suárez's theory of law. I intend to show that his doctrine of law can be understood more deeply attending to the role the intellect and the will play in its genesis, i.e. I intend to construct a view of the grounding of the law in the moral psychology of Francisco Suárez. The interaction between the intellect and the will make way for the recognition of the goodness of beings and the openness of human nature to formulate different practical courses of action and to self-determine itself towards those concrete forms of goodness. A comparison with the animal-sensitive circuit of action will be offered as a contrast.
\end{abstract}

Keywords: Francisco Suárez; moral psychology; praxis; freedom; animals.

\section{Introduction}

My aim in this paper is to show that Suárez's philosophy of law should be understood within the framework of his moral psychology, with particular attention to his notion of praxis. This thesis entails different presuppositions, mainly, that law must be understood within the general theory of the freedom of the will and of the intellect: Suárez's law theory is not only a way of understanding and acting according to laws; rather, it must be conceived under the paradigm of practical actions, attending to the genesis and structure of the law itself, according to its rationality and directionality, i.e. to the dynamics of the higher faculties of human nature. (In turn, these 
two tenets highlight the importance of language for Suárez's philosophy, and its place in the formulation and conception of laws.)

Thus, I will try to show some relations between language, the intellect as the root of freedom, and praxis in Francisco Suárez. This is, of course, not a simple, one-leveled correlation. It is actually a multifaceted account that should try to make justice to several Suarezian themes, among them: (1) The intellect as the root of freedom, and its capacity for complex knowledge, (and linguistic articulation) as a necessary component of praxis; (2) The will's proper role as distinct and complementary to that of the intellect, with a special emphasis on the notion of actus virtualis; (3) The reality of praxis as a habit of the practical intellect, and thus the habitual role-disposition of freedom and human action.

These different strands can contribute to a general outline the notion of law. Suárez is rightly recognized for the depth shown in De legibus ac Deo legislatore, but I think the case could be made that the psychological framework behind his theory of law can still benefit from further study, particularly into his psychology. Many insights can be gathered from new readings of his commentaries on Aristotle's De anima and Aquinas' Summa theologiae. Law should be understood as a (practical) statement that compels the will, and this requires the previous acknowledgement of the intellect's ability to produce such a statement, and the will's ability to commit itself to it.

I will proceed as follows. First (§1) I will present the notion of law, according to Suárez, as specifically directed to human beings, and unable to be applied to animals. I will then (§2) show how this requires a comprehension of the law in a practical-psychological setting, namely, as a practical disposition towards an end which can only be obtained through the particular dynamics of the higher faculties in human persons. The last section (§3) will conclude with some brief remarks on the need to understand the law in light of the doctrine of praxis as a habit of the practical intellect.

From an external point of view, these brief remarks could be of some use, perhaps, for two purposes:

(a) From a historical point of view, to focus some of the complex intricacies of Suárez's idea of freedom, and how it operates within the framework of the 
spiritual human faculties and their mutual interactions. As I have mentioned before, many different doctrines confluence to explain human action. Suárez's explanations owe a lot to Thomistic psychology, but he also makes use other authors (with a marked influence by Scotus) and shows a remarkable inventive to work out the psychological grounds of his legal theory.

(b) From a systematic point of view, I would argue that contemporary discussions on agency, moral, human, and animal psychology, could find a particularly rich series of interlocutors in Suárez and other Baroque and late-scholastic philosophers. More than being just a repetition of medieval authors, these scholars had already started to encounter and weave a complex synthesis with the first sprouts of modern science: their philosophy is only too conscious of the new grounds and argumentative needs. Suárez was not only a theologian and jurist, but he was well-read in the science of his time, including medicine.

\section{The humanistic dimension of law}

According to Suárez, "law" is "a common precept, just and stable, sufficiently promulgated” ["Lex est commune praeceptum, iustum ac stabile, sufficienter promulgatum] (De legibus, I, 12, 5). Both as a precept, and as promulgated (and thus binding on the subject's will), it is inaccessible for animals as subjects.

Of course, Suárez himself recognizes animals are not the proper subjects of laws (De Legibus I, I, 2), even though they can be said to be conformed to rules, insofar as, like all natural beings, their actions presuppose a previous order towards determinate ends. On the other hand, Suárez recognizes the difficulty in defining what "natural law" is, as a particular determination or requirement of nature corresponding to the human essence and its proper ends. He will link, in this vein, natural law to the notion of praxis, understood as the rational habit that directs mankind in general to practical truth, the "truth" of actions that fulfils our ends.

There is a double but entwined difficulty here, in having animals not being possible subjects of the law while also pointing at the founding 
"praxical” character of natural law. To deal with them Suárez must allude to the human capacity to formulate laws, on the one hand, and to the necessary rational potency that allows us to ensemble the kind of cognitive contents that allow us to speak about a "law". A law, in fact, presupposes the formulation of a concrete propositional content and (formally) requires its imposition as a rule that must be followed. The binding character of the law refers to its imposition by will of the legislator, an imposition which must find a correlate in human will, but the content of legal precepts assumes the existence of propositional knowledge. Only those subjects that can elaborate and understand practical judgments can formulate, acknowledge and follow laws.

The pertinent practical judgment supposed in a law precept demands the establishment of a voluntary and convenient order, that is to say, rational. The content of a law as a compelling judgment firmly establishes lawful propositions within the domain of practical reason, as formulations that acquire their significance in the context of actions, and therefore, of practical truth. It is here where human action, then, attains its own 'truth' and its direction towards determinate ends, as appropriate and desirable for human nature. The incapacity of animals to be subjects of laws does not then come only from their lack of free appetitive faculty: they are incapable of being subjects of the law from a previous "ontical" stage, insofar as they are incapable of being proper subjects of action, unable to formulate practical judgments (DA, I, 4, 11; Lecón 2014). ${ }^{1}$

This should not be taken as meaning that animals are wholly incapable of acting in a determinate way, or of 'making decisions' pertaining their actions. Rather this means that man is not pre-determined to an end in an a priori fashion. A proper feature of human freedom, according to Suárez, is our ability to self-determine ourselves to a proper end (or refuse to determine ourselves to it) in the more convenient way, according to our estimations. Only a being that can voluntarily pre-dispose itself (self-determination towards ends) to a concrete practical determination promulgated as a law

1 For the De anima texts' translations I have made extensive use of the translations in Sidney Penner's website (http://bit.ly/2cpOuOx; last access 30.VIII.2016) 
(the rational content of legal precepts) can be the subject of a law, and must therefore be determined by an order of proximate and remote ends, by a plexus of primary and secondary meanings.

What is this form of this particular openness of the human soul and why don't animals participate from it? According to Suárez, this is not a gradual difference. It is not that human animals are capable of 'more' actions, or that humans have 'more' possible ends to choose at their disposal. The difference is radical; it consists in human beings' ability to dispose themselves to their own ends, and is dependent on the different substantial forms of the animal and human souls (DM VI, IX, 4). ${ }^{2}$ It is indeed according to the substantial form that an existent's faculties arise ( $D A, \mathrm{I}, 3,7)$, and the former determines their perfection and reach $(D A, I, 4,3$ and I, 4, 11). That is why certain animals may act in ways that can be called analogous to human actions, and yet, animal minds have limits that become clear in the way they behave. Suárez is here working on a long tradition that recognized the existence of mental states in animals, a somewhat standard position (generally speaking) in ancient and medieval philosophy (Kaukua/ Ekenberg 2016).

Human actions may seem "intelligent" or prudent insofar as animals can lead themselves, even in the absence of the proper object of their acts. They do so with notable perfection, so that even in situations where the intention of their actions is not readily apparent or realizable, they direct themselves correctly. A hungry animal may be careful to face a bigger, more dangerous specimen. A sheep may run from a wolf when it picks up the sensible inimitia provoked by the latter's presence (even if it's the first

2 "Et confirmatur primo, nam si in re homo et animal nullo modo distinguerentur neque etiam equus et animal; ergo neque homo et equus possent distingui, nam quae sunt eadem uni tertio sunt eadem inter se; et quidquid est de essentia unius, erit de essentia alterius, et e converso; nam, si homo et animal in re sunt idem, quidquid est de essentia hominis erit de essentia animalis; et simile erit in equo; ergo idem erit comparando hominem et equum inter se; vel certe fatendum erit aliquid esse de essentia animalis in homine quod non sit in equo et e converso; ex quo sequitur animal non dici univoce neque secundum eamdem rationem de homine et equo, sed aequivoce, vel ad summum secundum analogiam quamdam proportionalitatis.". 
time it actually faces a wolf), but may refrain from doing so when the wolf is trapped in a cage. ${ }^{3}$

The ratio for this analogy may be found in the perfection of the internal sense, which Suárez explores in De anima VIII, 2: “The object keeps a proportion to the faculty. Now, the internal sense is the most universal faculty in its level. Therefore it has the most universal object, and such an object encompasses all that is sensible" (DA, VIII, 2, 1). It relates primarily to the common sensible and, modalizing it, to its "non sensatae" aspects, for example the ratio of inconvenient, enmity, the sensations of external acts and everything that can be known without representative species of the internal senses, including knowledge of the sensibles, their discernment, the memory of the past and the "iudicium practicum et speculativum de re" (DA, VIII, 2, 2).

Following Aristotle in De anima 413b 22, Suárez holds that every animal possesses an internal sense, but not all them with the same degree of sophistication: animals that possess only touch (and perhaps taste) and are incapable of conserving species in the absence of their object have a particularly imperfect internal sense. In contrast, animals with a more complex internal sense may be said to have "a certain animal prudence [quandam naturalem prudentiam] and sometimes even docility” (DA, VIII, 2, 4), This kind of prudence appears in animals with memory and hearing,according to a doctrine "taken from Aristotle in Metaphysics I [980b 21ss], wherein he holds that animals with hearing and memory also have prudence; though prudence understood, of course, not as a habit that allows them to consult what to do according to right reason, as per the definition of Ethics VI, but rather understood as a natural judgment on what is to be done rightly [iudicium naturale recte agendorum]. And this judgment is practiced as prudence would" (DA, VIII, 2, 5).

3 The examples of sheep and wolves were favorites of Avicenna (Black 1993). For a detailed study of Suárez's theory of the internal sense, cf. the now classic study (South 2001); on the methodological treatment of the problem of the internal senses in Suárez (Heider 2016); and finally, from the perspective of the senses as active or passive (Leijenhorst 2007). 
An animal is not a subject of the law because even if its actions are analogous to praxis, the internal sense which guides them is capable only of moving them to action according to the limits of understanding things only "sub ratione convenientis et disconvenientis" (DA, VIII, 1,9$)$. This ratio of convenience or inconvenience is not really a judgment on a reality, but just an impression with sufficient strength as to move the animal towards action (DA, VIII, 1,5$){ }^{4}$

In human beings, however, this kind of impression "acquires a greater perfection, for it is not only guided by natural instinct, but also by a greater knowledge and experience, and oftentimes it is also directed by reason" (DA, VIII, 1, 10). In animals, action is begun by the strong impression of a non-sensible modulation of an exterior sensible object; in this sense, an action occurs naturally wherever internal sense and appetite coordinate in a sufficient manner.

Reason, on the other hand, may introduce itself into this circuit. The "disruption" of the inner sense-appetite circuit opens up a "space" of possibilities; and this "space" is what allows the confirmation and self-determination of the will. As human beings are not therefore not simply moved by nature to action by the coordination of internal sense or appetite, we call their actions voluntary i.e. free. In this sense we may say that animals can direct their actions, but not their impulses, and that the direction the animal puts forward, even if analogous to human prudence, depends on the perfection or their perceptive systems, insofar as it is capable of retaining the species of absent objects (memory) and of acquiring the non-sensible impressions of convenience or inconvenience. The animal's reaction capacity, while being highly sophisticated, is in this sense formally different to reason's proper amplitude.

Animals may effectively cognize the order of the world and even change it to optimize it according to their own necessities. However, these changes will always be, if I may use this expression, of a "technical" nature. Not,

4 Here, Suárez explains that opinion always originates the motion of the appetite, but this is not the case with imagination, which moves the appetite only with a strong enough impression. 
of course, in the sense of the Aristotelian techne, because this is also an intellectual, practical virtue, that arranges physical actions according to rational likings by creating ends or arrays of intermediate ends towards determinate ends. Animal actions, according to Suárez, do not create or rearrange intermediate or determinate ends for actions, they do not question the ends they are predisposed for, they do not develop intermediate techniques (like the fabrication of instruments), nor do they in general employ any tools beyond those immediately at their disposal to expand their reach. According to their memory and capacity to learn, animal techniques may be more or less pre-determined and adapted towards its environment, so that, for example, an animal that sees its routine efforts impeded half-way may have no other choice but to start over from the beginning.

In the end, "While Suárez's animals are fully sentient and beings full of feelings, they are also creatures of necessity, predetermined in their responses and actions by God, and bereft of true agency and choice." (Alves 2011, 45). The use of the word "necessity" could perhaps be qualified: animals cannot determine their ends, and thus are in a sense finally caused and pre-determined (DM, XIX, I, 12).

Why are animals capable of certain prudence but bereft of true agency? Because they are incapable of self-determination, which in turn, is due to their inability to form complex and universal propositions regarding the relations between means and ends. Even if both animals and human beings can be said to act in teleological contexts, only human action implies an internal adaptation to the teleological order itself $(D A, \mathrm{I}, 4,10){ }^{5}$

\section{The rational 'openness' of practical judgments}

The grounding of all law in Suárez is the eternal law as the order of everything to the divine Will. It is only in a second moment in which this law appears as 'inscribed' in human reason, as the principle of all right moral

5 Even the heavens are not moved by an internal principle. The motor of celestial bodies them is an extrinsic rational principle. 
principle (i.e. as the habit of synderesis). The propositions that arise from this habit are the natural law, on which natural rights are based. Natural law contains general principles of action, valid for all persons regardless of their context. (Of course, on the other hand, their application cannot be this abstract.)

We should here consider, then, two different strands that are present in every law. One is the content of the law, the precept that it espouses. The other one is the obligatory nature of the law. As Suárez formally defines the law attending to its latter, obligatory nature, it may seem adequate to highlight the voluntarist approach of Suárez's law theory. But this is of course only half of the law's character, for only a practical proposition of a certain kind may be promulgated as a law, and therefore the formation of the practical principle is just as integral to the law as its imposition. Granted, if it is not promulgated by an authority, it cannot be called a law but in an improper sense (and in section \$3 I will talk about this issue regarding natural law); still, not every sort of proposition can be proclaimed as a law either.

There is a distinction, then, of two levels of the law, and both should be taken into account when talking about this notion. To employ the terms of A. Vigo (Vigo 2011) it is possible to recognize a representational primacy of the intellect, and a motivational primacy of the will: the intellect cannot force the will to determinate itself towards a particular course of action, but the will cannot of course decide on any course of action that hasn't been previously suggested by the intellect ( $D A$, XII, 1,7$)$. This in turn leads to a refined construction of what right reason should mean.

For the moment, let us acknowledge that our ability to generate representational practical circuits means that human beings not only operate in teleological contexts like animals do, but rather that we constitute our own teleological contexts. It may be objected that, without any qualification, this expression may result in absurd positions that do no justice to human limitations. Indeed, Suárez knows that, regarding the first acts of the (theoretical and practical) intellect and the will, there is no freedom of specification: there is only freedom of exercise for the will (and indirectly 
for the intellect) (DA, XII, 2, 13). The expression must then refer not to the direct determination of the intellect and the will (truth, praxis, the good), but to the specification of secondary, individual acts. The theoretical intellect is immediately directed towards truth, but it must then observe this orientation in the gradual knowledge of nature and itself. The will is immediately specified towards the good in a general sense, but this only shows that, along with the practical use of the intellect, it must acquire specifications through principles of action and concrete operations. This is where freedom comes into its full exercise, and where the construction of our own teleological horizons may be said to establish a specific form of life, proper to human persons.

Retracing what I said above, the first step corresponds to the cognitive or representational primacy of the intellect. In fact, knowledge, both sensible and rational, occupies the first step in any action circuit: without some form of knowledge, it would be impossible for any appetite to be moved. An appetite, sensible or rational, can impose itself upon the cognitive faculties, but always on the account of a previous datum that arouses it in some way. An animal may feel hunger and, moved by this appetite, compel its cognitive faculties to look for food, but it was the conscience of hunger that started the process.

In the case of animal action, it is the appetite itself, according to the impression of the object and the intention acquired by the inner sense, the one that confers the ratio of end to an object, thus triggering animal action $(D A, \mathrm{X}, 1,2)$. There is no discourse in this sensitive circle of action, and thus, no freedom. "Freedom comes from an indifference of reason" (DA, XI, 3, 3). There is of course immanent action, unlike the movement of inanimate objects, which only improperly can be said to lean towards an end.

The sensible circuit may be called 'animal prudence' insofar as it requires the cognitive moment and an attached reason of convenience or inconvenience, the reason being that the union of the cognitive and attractive notes that impress upon the appetite and incite animal action seem to form a picture that corresponds to the Aristotelian practical syllogism (Vigo 2010). The practical structure of animal action allows for the analogy with 
human action, but again, the inability of animals to determine their own ends keeps it from being a true form of praxis; animals are directed in such a way that they cannot establish different ends for their actions, and their objects are always concrete, singular, material goals $(D A, \mathrm{X}, 1,3)$.

In a human practical syllogism, on the other hand, the intention of the internal sense is substituted by a practical principle; or rather, the intention of the internal sense is incorporated to the new cognitive circuit of human rationality. Indeed, the sensible appetite is acknowledged by the intellect and constitutes a possible motivation for action among others, always leaving room for the will's capacity of self-determination. Moreover, the practical premise alludes to a composition (expressed in propositional terms) that allows for re-arrangements of different direct and indirect frameworks of means-ends, owing to the openness of intellect and will to the specification of their primary objects.

Indeed, precisely because the appetite cannot by itself determine the rational appetite, the intellect must provide a practical judgment. The intellect can deliberate in a practical setting about means and ends, but as it cannot determine the will, the latter's freedom of specification is preserved. The intellect configures the representational principle of action, and arranges the order of ends, but the operative primacy belongs to the will, which can freely elect and operate over the proposed means and ends of the intellect (DA, XII, 1,7$).{ }^{6}$ There is in this sense a harmony in our rational faculties: "the will intends the end and thus it is its prerogative to influence in all faculties that can lead towards such an end. (...) By this mechanism a reduction is obtained in all human faculties towards a unified factor, primary and intrinsic, that influences on all others, in such a way that the structure of human nature becomes adjusted and harmonious" (DA, XII, 1, 6).

Still, the freedom of the will is said to be dependent on the intellect in the sense that "the freedom of the will consists in the possibility to love and not to love the proposed good object; however, this possibility is not

6 And also DA XII, 2, 5: "[free will] means that the faculty, having all the requirements to act, can fall into action and not fall into action" [possit exire in actum, et non exire, positis omnibus requisitis ad agendum]. 
arbitrary, but instead the will can love it insofar as it finds an aspect of good" (DA, XII, 2, 10).

As the intellect is necessary to establish this aspect of good, the practical premise becomes a sine qua non requisite of human action. This aspect of good in turn is linked to the notion of end, and that is why the practical intellect must pronounce itself and establish ends for actions, i.e. look for ends that are not always provided by the sensible appetite. Even more, the finality sought by the intellect must be integrated into a superior order of ends that contemplates those of the appetite, but integrates them into a new comprehensive framework. This is because, if the intellect is primarily determined towards truth, it has to recognize the truth of beings, which is linked to its perfection, and in that sense is comparable to the perfection of other beings. ${ }^{7}$

And this is precisely why we can speak of an order of means and ends: because no end that can be considered a "final end" is an absolute one, and thus it is possible to construct different orders of good beings according to different sense of perfections determined by different criteria. "Practical truth" means precisely that there is not a unique possible course of action, but many, and innumerable are also the combinations, according to whether we highlight one aspect of goodness or another ( $D A, \mathrm{X}, 2,3)$. Of course, this also means that "failure" in a practical setting is that much more possible. In this fashion, Suárez attends to the enormous multiplicity of possibilities in human life. The will "is not determined to follow any particular good in this life, neither regarding its exercise (for we cannot clearly and simply a necessary, clear aspect of the good in it), nor according to its specification (for there is in this life nothing that is mixed with elements of evil and difficulties)" (DM, XIX, 5, 13). In our existence as wayfarers we cannot perceive a political-moral order such that our wills need to be taken or decanting to it.

At any rate, the openness of the will towards goodness in different senses and orders presupposes the openness of the intellect, because it is the intellect the one that brings about "measure and rectitude" (DA, IX, 9,

7 On the complicated matter of the relation between truth and goodness one may consult the very useful study (Darge 2004). 
16). This is why we need not only the capacity to form judgments regarding the direction of human actions, but even before that, the theoretical knowledge of their nature and their subject (DA, IX, 9, 3; IX, 9, 5). And so Suárez recognizes that even if free will belongs to the rational appetite, the root of freedom resides in the indifference of the intellect $(D A, \mathrm{XII}, 2,10)$. Suárez can therefore claim that the intellect is formally more perfect than the will. ${ }^{8}$

What then is the specific differential quality of the will as the faculty that allows for the specification and exercise of freedom? Suárez recovers here the notion of actus virtualis, a doctrine that had already appeared in previous authors, and most notably in Scotus, though perhaps not as clearly.

Indeed, following Scotus, Suárez recognizes the will as the properly free faculty, insofar as the intellect is naturally determine to acknowledge truth, whereas the will is not determined to conform to any determinate good or end. This indifference is the openness of freedom, and correlates with what Suárez calls actus virtualis. ${ }^{9}$ The will is not determined by the impulse of the intellect nor the object, but by a certain "virtual reflexion".

In De anima XII, II, Suárez raises the question of the freedom of the will. He contemplates various objections that would prove that the will's act is not free. Among them, he asks: "if our power is free, then either [it is free] while it acts or before it actually acts. But not the latter, for in that case it has not yet acted [at all] and therefore has not acted freely. But neither when it is acting, since then it acts necessarily. For it is necessary that a thing be when it is. And when it is acting, it is necessary that it be acting” (DA, XII, 2, 3).

This objection will allow Suárez to clarify many principles and distinctions. Among them, in the first place, the difference between the different senses of freedom of the will (cf. n. 6): absolute, on the one hand, and the elicitation of acts on another. Regarding the freedom of the will in an

8 Even if the intellect is not formally free, it can be said to be more perfect than the will because it is its rule. (DM, XIX, 5, 25). I have written on the order and perfection of the intellect and the will in González-Ginocchio 2014).

9 On Scotus's formulation of this doctrine cf. I. D. Scoti, Quaestiones super Metaphysicorum Aristotelis IX, q. 15, n 22. 
absolute sense, Suárez claims "the will has freedom and dominion of its operations or actions" (DA, XII, 2, 7). Indeed, aside from the Scriptures, our own experience testifies that "we ourselves see that we act and we cease from that activity when we wish. And in this human beings differ from brute animals and the judicious from the insane" (DA, XII, 2, 8). We are therefore responsible for our actions, that deserve praise or blame. And this is a first principle of rational nature. More generally, Suárez explains that

human beings are by nature lords of their actions. And this seignior means being capable of, in accord to their freedom, exercise those actions or not. Therefore they are free. The first premise can be proved because human beings are lords of other things, for all natural reasons claims that human beings are capable of seniority and that taking something awake from hisoen is bad. And this seniority consists on being free to employ your possessions (DA, XII, 2, 8).

To sum up, being a lord of your actions is the same as the formal freedom of the will, for out of the liberty of external actions we extend the idea of free to its principle. Suárez immediately refers this to the non-determination of the rational appetite.

Freedom consists formally in the will, for it consists formally in the indifference over election. A human being is free insofar as it can employ this or that. It also consists of the free use of its operations. But choosing and employing other powers is something proper of the will, as can obviously be seen. Therefore the will pertains formally to the will and every operation is free insofar as it is subject to the will (DA, XII, 2, 8).

In line with the previous tradition, Suárez remembers the difference between universality and the perfection of intellect, because the intellect can find a feature sub ratione boni in any intellect of the world. Against Sylvester of Ferrara and Soncinas, Suárez will insist: it is not that the will wants the object to be presented as the best and more agreeable, for in this case there would be no free will: following the best good proposed by the intellect in a correct manner correctly would be sufficient. Suárez will always highlight the fact that the will specifies its act. It can therefore adhere itself towards 
an object presented as the best (or not), and it may even wish a very different one, with a ratio of good that is less than the one in the first example. ${ }^{10}$

In this fashion Suárez attends to the multiple possibilities of human life, and the multiple practical paths, as said above.

But how can the will determine itself?

To look for a solution to this matter we may look to DM XIX, a treatise that dedicates many sections to free causality (II-IX). Here we can find an exposition of "formally free potencies". Formally free here means, of course, intrinsically voluntary, precisely in light of the self-determination of the will regarding the exercise of its act. The will may compel another faculty, and the latter would therefore act "freely", but that does not make it a formally free faculty, in the same way as an act of love is voluntary (DM, XIX, 5, 17).

Suárez will clarify: the extrinsic voluntary act is actually the object and effect of an intrinsic voluntary act. That is to say: the will moves the inferior faculty (which is therefore its object) to the realization of a certain action (and thus it is also its object).

On the contrary, the act that is by itself intrinsically voluntary cannot be compared to the proper object or effect of that other act by which it is voluntary, which is voluntary by itself and properly is not an object or effect of itself. Therefore, it has a distinct object towards which it is directly intended and it is the effect of the faculty that realizes it, and is only voluntary by means of a certain virtual reflection that it includes in itself; that is why we say that something is wanted by way of an act, not by way of an object (DM, XIX, 5, 17, in finem).

The idea of quondam virtualem reflexionem is complex, but at least it seems to entail that an intrinsically voluntary act is free because the will is a faculty that, because of a "superabundant perfection" (a phrase of Scotus) is capable of determining itself towards its object.

10 The intellect may be determined -heterogeneously- by the will in its exercise; before a true object, it is obliged to assent. The will, on the other hand, is not determined to assent to an object that appears clearly as good: "And this is because the ratio of truth is just of one kind, so that, if something is had as true, all falsity is excluded. On the other hand, the ratio of goodness is not only one, so that goodness may be mixed with other negative aspects" (DA, d. 12, q2, 13). Only God is excluded from this dialectic: only in Him may we find the maximum ratio of good. Thus, the will may freely choose ends (without deliberation) and means (with deliberation and counsel). 
And a little bit further, Suárez insists: "when the will is carried towards the object, it does not only want the object, but also wants the virtual exercise of its own act, for any intrinsically voluntary supposes a virtual reflection on the will, insofar as this is not necessarily determined towards an object; instead, in a previously ontic way it sel-determines itself towards it” ( $D M$, XIX, 5, 17, in finem).

This Suarezian thesis is repeated in a somewhat broader sense in other passages viz. De voluntario et involuntario (d. 1, I, 2-3) ${ }^{11}$. The virtual reflection of voluntary acts is determinant in such a way that it wholly differentiates it from any other mode of agency. ${ }^{12}$

\section{Conclusion}

Suárez theory of law is built upon the idea of natural law as a form of more concrete expression of eternal law in our souls, and the way to construct this notion of natural law is through the idea of synderesis as a practical habit.

Once we have knowledge of our own nature, and the world we belong to, our rational faculty is able to suggest more or less concrete ends, thus establishing principles of action, from the first principle of practical reason (synderesis) to the more concrete propositions guiding our movements. That

11 "At vero ipsa interior volitio, quae est actus elicitus, ita est voluntaria, et volita ut actio, seu actus, ut non sit proprie obiectum volitum, quia necesse est huiusmodi actum habere obiectum a se distinctum, circa quod directe versetur. Unde solum ipse est volitus intrinsece, et per se ipsum per quondam virtualem reflexionem, quam in se includit, et ideo dicitur per modum actus, non per modum obiecti" (De voluntario et involuntario d. 1, I, 2).

12 Thus, we find in De voluntario et involuntario d. 1, I, 4: "Addendum vero est etiam ipsum actum quatenus in facto ese informat voluntatem, et constituit illam volentem, non tantum constituere illam volentem obiectum, sed etiam ipsummet actum per virtualem reflexionem in illo inclusam, quod etiam afendo de voluntaria productione Spiritus S. explicui libr. 6. de Trinit. cap. 4 a num. 7. Nam actus ipse, ut actus est, intrinsece includit, quod sit volitus, neque intelligi potest voluntatem constitui volentem, id est, voluntarie tendentem in obiectum, quin virtualiter velit ipsam tendentiam, seu inclinationem, ut si per possibile, vel impossibile amaret obiectum per amorem impressum ab alio fine efficientia eius, revera non tantum non eliceret ipsam efficientiam, sed etiam neque ipsum amore, neque voluntarie, et spontanee amaeret; ergo signum est huiusmodi actum, non solum denominati voluntarium a dependentia in genere causae efficientis, sed per se upsum formaliter ex vi suae informationis, in quo differ huiusmodi actus ab omni alio, qui non sit a voluntate elicitus." 
is why I have suggested this setting in moral psychology to aim for a deeper understanding of the notion of law in Suárez. This entails recognizing the primacy of the intellect in the genesis of the law; this primacy does not refer to the promulgation or obligation of a law but to its formulation and (reasonable) content. The will is then able to determine itself to practical judgments formulated by the intellect, or not, and eventually the will of the legislator will promulgate a law. But without this previous moment, and the recognition that a complex knowledge of the world, of human nature, and the possible practical relations between them can and should be articulated by the intellect and provided to the will, no legal formulation, and indeed no practical principle, would be possible.

\section{Bibliography}

Alves, Abel A. 2011. The animals of Spain. An Introduction to Imperial Perceptions and Human Interactions with Other Animals, 1492-1826. Leiden: Brill.

Bauer, Dominique. 2015. “Custom in Francisco Suárez’s De lege non scripta. Between Factuality and the Legal Realm.” Anuario de derecho canónico 4: 351-370.

Black, Deborah. 1993. "Estimation (Wahm) in Avicenna: The Logical and Psychological Dimensions.” Dialogue 32: 219-258.

Darge, Rolf. 2004. "Vom Gutsein der Dinge. Suárez Theorie des ontischen Guten und die Metaphysiktradition." In Francisco Suárez "Der ist der Mann" (Heidegger). Homenaje al Prof. Salvador Castellote, 133-159. Valencia: Facultad de Teología San Vicente Ferrer.

Freddoso, Alfred J. 2012. "Oh my soul, There's Animals and Animals: Some Thomistic Reflections on Contemporary Philosophy of Mind." http://www3.nd.edu/ afreddos/papers/Oh\%20My\%20Soul.pdf

González Ginocchio, David. 2014. "Agencia, sensibilidad e intelección: sobre la raíz de la libertad en Escoto y Suárez.” In Los fundamentos antropológicos de la ley en Suárez, edited by José Ángel García Cuadrado, 89-114. Pamplona: Eunsa.

González Ginocchio, David. 2016. "El hábito como horizonte de comprensión de la praxis: quién es 'ley para uno mismo’ según Francisco Suárez." In Perspectivas del De legibus de Francisco Suárez, edited by Mauricio Lecón, 49-60. Pamplona: Cuadernos de pensamiento español, Servicio de publicaciones de la Universidad de Navarra.

Heider, Daniel. 2016. "Aquinas on Sensitive Powers and Suárez's Reductionism in De anima." In Pasiones y virtudes en la época del Greco, edited by José Luis Fuertes, Manuel Lázaro and $\mathrm{M}^{\mathrm{a}}$. Idoya Zorroza, 139-150. Pamplona: Eunsa. 
Kaukua, Jari/ Ekenberg, Tomas (eds.). 2016. Subjectivity and Selfhood in Medieval and Early Modern Philosophy. Dordrecht: Springer.

Knuuttila, Simo. 2015. "Suárez’s Psychology.” In A Companion to Francisco Suárez, edited by V. Salas, \& R. Fastiggi, 192-220. Leiden: Brill.

Lecón, Mauricio. 2014a. Acción, praxis y ley. Estudio metafísico y psicológico de la acción legislativa en Francisco Suárez. Pamplona: Eunsa.

Lecón, Mauricio. 2014. “Sobre la imposibilidad de la ley en los brutos.” In Los fundamentos antropológicos de la ley en Suárez, edited by José Ángel García Cuadrado, 195-204. Pamplona: Eunsa.

Leijenhorst, Cees. 2007. "Cajetan and Suárez on Agent Sense: Metaphysics and Epistemology in Late Aristotelian Thought." In Forming the Mind. Essays on the Internal Senses and the Mind/Body Problem from Avicenna to the Medical Enlightment, edited by Henrik Lagerlund, 237-262. Dordrecht: Springer.

Penner, Sydney. 2013. “Free and Rational: Suárez on the Will.” Archiv für Geschichte der Philosophie, 95: 1-35.

Scoti, Ioannis Duns. 1997. Quaestiones super libros Metaphysicorum Aristotelis, edited by G. Etzkorn et al. St. Bonaventure, N.Y.: The Franciscan Institute Press.

Suárez, Francisco. 1856. De voluntario et involuntario, in Opera Omnia (t. IV). Paris: L. Vivès.

South, James B. 2001. “Francisco Suárez on Imagination.” Vivarium 39: 119-158.

Suárez, Francisco. 1978-1991. Commentaria una cum quaestionibus in libros de anima. 3 vols., edited by Salvador Castellote. Madrid: Sociedad de Estudios y Publicaciones.

Suárez, Francisco. 1960-1966. Disputaciones metafísicas. 7 vols., edited by Sergio Rábade Romeo, Salvador Caballero Sánchez y Antonio Puigcerver Zanón, Madrid: Gredos.

Suárez, Francisco. 1981-2012. Tractatus de legibus ac Deo legislatore. Corpus Hispanorum de pace. Madrid: CSIC.

Vigo, Alejandro. 2010. "La concepción aristotélica del silogismo práctico. En defensa de una interpretación restrictiva.” Diánoia 55/65: 3-39.

Vigo, Alejandro. 2011. “Intelecto, deseo y acción según Francisco Suárez.” In Razón práctica y derecho. Cuestiones filosófico-jurídicas en el Siglo de Oro español, edited by Juan Cruz, 11-29. Pamplona: Eunsa.

Westerman, Pauline C. 1998. The Disintegration of Natural Law Theory. Aquinas to Finnis. Leiden: Brill.

Westerman, Pauline C. 2007. "Suárez and the formality of Law." In Politische Metaphysik: Die Entstehung moderner Rechtskonzeptionen in der Spanischen Spätscholastik, edited by Matthias Kaufmann and Robert Schnepf, 227-237. Frankfurt am Main: Peter Lang. 